\title{
A PLAN FOR THE NATIONALIZATION OF RAILROADS
}

Seven men have been delegated to dominate the interstate commerce of America. Does not that fact in itself spell failure? What practical man knowing the stupendous task imposed upon those seven men would imagine even for one moment that they or any other single body of men could successfully cope with it? The Interstate Commerce Commissioners have done their best. Angels could do no more. But they have utterly failed to satisfy either the public or the railroads. Nevertheless, they have performed at least one high public service. They have demonstrated that no Commission, however intelligent and conscientious, can control the tumultuous cross currents of public demands on the one hand and those of railroad financial necessities on the other. They have shown that neither courage nor brains will sustain such an effort and those who attempt it will sooner or later be drawn into and overwhelmed by a veritable whirlpool of thought and action.

Railroad problems are too complex to be solved by a commission. Commissions to listen to public complaints, correct abuses and regulate service are a success. But a commission to control railroad rates and thereby dominate the railroad world of this country is a menace and a failure.

The combining of legislative, judicial and executive functions is contrary to American history and policy. It is despotic in its nature, dangerous in its power and disappointing in results. It cannot and should not last. It never should have been attempted. Chancellor Kent in his Commentaries said that the separation of the legislative, judicial and executive departments was "essential to peace and safety in any government." One hundred years later, in the United States Senate, on September 30, I9I4, Senator Borah, speaking of Commissions, said: "We not only place in the hands of these few men the ordinary reins of government, but we clothe them with an unlimited and undefined discretion, which amounts to the lodgment of arbitrary power."

Rate making is a legislative function, while rate review is a, judicial function. How can we expect a commission to perform both, especially in view of the dismal failure of the legislature and courts to solve the problems of railroad rate making and 
railroad finance? Railroad Commission rule is based on the economic mistake of authorizing the buyer to fix the price, with a court to prevent absolute bankruptcy of the seller. It requires no foresight to see that that sort of thing cannot last. The public is already dissatisfied with the condition of the transportation business in this country under commission rule.

Not very long ago the modern Public Service Commission was characterized by a Federal Court as being "practically complainant, prosecutor, judge, jury and sheriff." What would the court say now when the legislative power of rate making has also been added to its duties? This leads to chaos in the way of unexpected and startling changes in decisions and policy. Witness the recent volte-face of the Interstate Commerce Commission in granting an increase in railroad rates.

The reason of this resort to Commission rate making is plain. The railroads, and more particularly the Wall Street financial magnates controlling them, were fast attaining ascendency over the country, its politics, its wealth, and the very government itself. Congress was impotent. The courts interdicted abuses, only to see them reappear in another form. Government ownership was seriously suggested as "the one best" remedy. Then came the hope of avoiding this issue by Commission rule and the country eagerly grasped at it. The net result is that we now know that the titanic conflict of interest between the railroads and the public cannot be settled by mediation and compromise. They have got to be united in some way.

We cannot go back to the old system of free railroading. Even railroad men admit that. It is dangerous, full of abuses, and altogether intolerable. Witness the New Haven episode. The country has had enough of that kind of railroad control.

Government ownership is still available, but the country is afraid of it. It is incompatible with our republican institutions. It would dominate the government itself, in politics, finance and policy. It would mean an office-holding oligarchy. Many years ago a famous Italian Investigating Commission said "Politics would corrupt the railways. And the railways would corrupt politics." Cannot the public and the railroads be united on some safer plan?

What are the elements of the problem?

Competition: President Ripley of the Atchison, Topeka \& Santa Fé Railroad Company, on October 24, I9I4, said: 
"Every night five magnificent trains leave Chicago at practically the same hour for Kansas City. Each train carries every modern device for the comfort of passengers, and not one of them is loaded to its capacity.

"Six trains leave Chicago for Omaha nightly and five for St. Paul, and of all of them the same may be said.

"Probably one of these trains-certainly two of themwould amply care for all the business and a great saving would result from discontinuing the other four. This is only one instance of what could be accomplished by coöperation, which, by the way, is forbidden by law.

"Every one knows that if all the roads reaching Kansas City were under one management the business could be done better and cheaper."

Can anyone justify such waste as that? Is it any wonder that railroad rates are raised on the one hand, while railroad finances are near the bankruptcy point on the other? Competition among our railroads is still the law, but it is breaking down in spite of the law. George Stephenson, the originator of the railroad locomotive, foresaw this inevitable trend in the railroad business seventy-five years ago. "Where combination is possible," he said "competition is impossible." For more than thirty years thereafter the British Parliament legislated against the consolidation of railroads. That legislation proved to be utterly futile. In 1872 , a parliamentary committee made an elaborate and exhaustive investigation of the subject. In its report it said that consolidation "had not brought with it the evils that were anticipated, but that, in any event, long and varied experience had fully demonstrated the fact that, while Parliament might hinder and thwart it, it could not prevent it." That was forty years ago. To-day the railroads in England have been consolidated into a few great systems, which, after long obstruction, have been sanctioned by the government itself. Mr. Acworth, the leading railway economist in England, said, in 1908:

"Competition is an instrument that is at this moment breaking in our hands. . . . We must, I think, assume that competition, which has done good work for the public in its day, is practically ceasing to have any real operation in regulating English railroads."

In America, competition is breaking in our hands even faster than in England. Whenever the Government breaks up a combination, as it did in the Northern Securities case, the Southern 
Pacific case, and the New Haven case, the result is like the slash of a sword through water; the waters come together again in a new combination. Competition between railroads, such as that described by Mr. Ripley, would disappear with the consent of the American people, if the American people themselves really controlled the railroads. That is the essence of the plan proposed below.

Railroad Financing: It requires from $\$ 500,000,000$ to $\$ 750$,000,000 every year to pay for necessary railroad expenses, terminals, rolling stock and improvements. This vast sum has been raised hitherto by new issues of stock and bonds. But the public will no longer buy the stock and bonds. Investors are afraid. How is the money to be obtained? It is very evident that it can be obtained only by uniting the railroads and the public in some way. How can that be done? Certainly not by a temporary makeshift such as sudden increase of rates. That simply means more warfare.

Profits: No plan which excludes the public from future profits of the railroads will avail. An effective union of interests must be based on the solidarity of partnership in profits. That was the key that opened the "Regional Banks."

Control: In Washington, on December 26, IgI4, Professor Grey, the President of the American Economic Association, said: "The American public has thoroughly made up its mind to have efficient control, according to its own idea of effective control, or to have public ownership."

The late J. Pierpont Morgan was right when in testifying before the Pujo Committee he said "Without you have control, you cannot do anything." He made sure of that control by seeking and gaining the proxies of the many small stockholders and voting them in favor of his own nominees for corporate directors. In the Government's brief of the law in the Union Pacific case, the following appears:

"It is a well known fact that one holding less than a majority of the stock of a large railway company, and having possession of the transfer books, can easily control the railroad, for the reason that such stock is widely scattered, the full amount is never voted and the officers are in position to procure proxies and thus vote stock enough to control at meetings."

Striking illustrations of this are found in the amount of stock which directors hold in the companies whose stockholders they 
represent. An affidavit in the Government suit above referred to contains the following:

"When we say that Harriman controls certain properties, we do not necessarily imply that he actually owns a majority of the outstanding stock. Perhaps the most fruitful lesson of his career is the revelation of the extent to which a few men can control our transportation systems while having only a very small personal ownership in them."

The syndicate controlling the Union Pacific and the Southern Pacific owned less than I per cent. of the stock, and at the same time were issuing $\$ 100,000,000$ of securities; directors of the American Telephone and Telegraph Company a year ago owned but 5 per cent. of the capital stock, according to its books; directors of the New Haven at the time of its collapse owned individually only 2 per cent., and even as the representatives of corporate stockholders their direct interest amounted to only I3.7 per cent. of the total capital stock; the Vanderbilt family in Igog owned less than 8 per cent. of the New York Central stock; James J. Hill testified a few years ago that he owned only about 7 per cent. of the Great Northern system.

Mr. Jacob Schiff, in his recent testimony before the Industrial Commission, solemnly asserted that the stockholders should take a more active part in corporate affairs.

You might as well ask the clouds in the air to propel the railroad locomotives. The stockholders are multitudinous, widely scattered, many of them women and estates. They give their proxies to whomsoever is in control-blindly and automatically. Even when their confidence is abused they are helpless and take their losses. They are derelicts adrift on an unknown sea, without chart, compass, landmark or pilot.

It is here that our whole railroad system breaks down. It is here that the whole trouble originates. Here it is that a reform must start if government ownership is to be avoided. The control of our great railroad systems by a group of bankers or by a single family, owning but a small proportion of the capital stock, must cease. If it does not, we shall come to Government ownership very swiftly. The "Regional Bank" plan recognized this state of affairs, as to the great banks in New York City controlling the whole banking system of the country, and that plan put the control, not in the hands of a few New York banks or bankers, but where the public would be safe. 
Expense: Tens of millions of dollars are being wasted and the time of tens of thousands of men is being frittered away in contests growing out of Commission control. The two New York Public Service Commissions alone expended $\$ 2,450,099$. I 5 in I9I3, and $\$ 3,792,884.74$ in I9I4. And forty-five states have Commissions, while even municipalities are beginning to appoint local Commissions to complete the work of baiting quasi public corporations. The aggregate expense is enormous. It would pay the interest on vast sums which might better be invested in railroad needs. And then there is the array of railroad clerks, other employees and officers, who do nothing but prepare for and attend Commission contests. Last, but not least, are the lawyers conducting the litigation.

Litigation: The pen fails to portray the portentous flood of litigation, and like Homer we are impelled to ask for higher

- inspiration. "Sing, goddess, of the destructive wrath of Achilles." Lawsuits without number, resulting in what? Contradictory rulings and confusion worse confounded. It is like the foot-by-foot battles of the Germans and the Allied forces on the Meuse and the Marne. Carlyle's Smelfungus would have viewed with dismay the anarchy of litigation that now prevails, and with a snort would have burst forth,

"Glass crackers, fire balls, flaming serpents, sleeping gun powder, burning dust flashing up sky high on a sudden, heels-over-head in a torrent of roaring debris. Infinite owlery. Floundering stupidity at the top of the world. Unintelligible pipe clay, and dreary continent of sand and cinders."

\section{But enough!}

Real Public Control: In I908, the writer, in the sixth edition of his work on Corporations, set forth in the preface a proposition that a corporation be organized by Act of Congress to place in the hands of the public the control of the railroads of America. This was to be done by that corporation acquiring, owning and voting the stocks of the present various railroad systems. The control of that holding company was to be in the hands of the public by control of its board of directors. In I9I3, in the seventh edition of the same work, the same proposition was elaborated, with the further idea that the annual profits of the railroads, over and above a fixed dividend, should go to the public. This time the proposition attracted the attention of many well informed and sound thinking men. 
Then came the "Regional Bank" Act of Congress of December 23, I9I3, which familiarized the public with banks incorporated by Act of Congress, embodying the idea of the holding company, controlled by a mixed directorate, and dividing the profits between the Government and the stockholders. On April 4, r9I4, the writer published an article in "Harper's Weekly," pointing out that all this might equally well be applied to railroads, under a similar "Regional Railroad" plan. The reception of that suggestion shows that what appeared revolutionary in I908 is accepted as evolutionary in I9I5. President Ripley of the Atchison, Topeka \& Santa Fé Railroad Company favored it, in an address delivered in Kansas City, October 24, I9I4, and William C. Van Antwerp, one of the Governors of the New York Stock Exchange, endorsed it, in an address delivered in Indianapolis December 15, I9I4.

It is the purpose of this article to explain in some detail the practical operation of the writer's long considered plan, which now seems almost if not quite abreast of the times, and which, if adopted in substance, will in his judgment avoid a disastrous experiment in government ownership.

(I) Four "Regional Railroad" corporations would be incorporated by Act of Congress-one for the East, one South, one West, one for the Pacific and Northwest. Each would offer its stock in exchange for present stock of railroads in its territory. Condemnation would be resorted to if necessary. Control of railroad annual elections, and hence the naming of railroad directors and control of the railroads themselves would thereby follow. One-third of the directors of the "Regional Railroad Companies" so incorporated would be named by the Government; one-third by the stockholders of the "Regional Railroad Companies," and one-third by the present railroad companies' executive staff. Each Regional Railroad Company by owning the stock of the present existing railroad corporations would control the annual elections of the latter and could elect its directors. The Regional Railroad Company would be relied upon to name proper directors of the present existing railroad corporations. The control of the railroads would thereby be vested in a new body of men, namely, the directors of the "Regional Railroad Companies" operating under a federal charter, and selected onethird by the Government, one-third by the new stockholders, and one-third by the railroad staff. These proportions could be varied. If necessary all of the directors could be named by the Govern- 
ment, which would be far better than having the Government take the title, ownership and direct management of the railroads themselves. In any event the railroad staff should name one-third of the directors. Vice President Atterbury of the Pennsylvania Railroad, in an address delivered February 9, I9I5, emphasized the importance of this when he said,

"My suggestion is that a minority of the railroad commissioners of the States and Nation should consist of men trained in the practical conduct of railroad affairs. I suggest that all appointments should be for life or during good behavior; that the salaries should be such as to attract the ablest brains in the country, and that these positions should be surrounded with such prestige and honor that any citizen would feel that he could serve his country and his fellow man in no more exalted capacity than in representing the people in promoting, encouraging and regulating the development of its transportation agencies."

The holding company has been, during the past twenty years, the device by which the consolidation of railroads and industries has been accomplished in the United States. Under it, great railroads have gathered in other railroads. These great railroads themselves are held in the control of Wall Street, through interrelated groups of institutions controlled by a few men, which, for practical purposes of control, are nothing more nor less than a group of security-holding companies. The "Regional Bank" plan, now in operation, is the holding company plan, all the stock of the Regional Banks being held by other banks, and none by individuals. This is or soon will be a fact familiar to the American people and will smooth the way for Regional Railroads.

(2) Dividends on the stock of the "Regional Railroads" would be guaranteed by the Government. "Regional Railroad" stock, the dividends on which were guaranteed by the Government, would not only furnish railroad money cheaply, but would be equal to a United States bond, or English consol, or French rente. It could be held by banks and trust companies and used as a basis for currency on a par with United States bonds. It could be issued in ten dollar shares and would furnish an absolutely safe security for the savings of the poor and the accumulations of the investor. It would be equivalent to a national savings bank for millions of people. It would be preferred to the new postal-savings-bank plan of the United States Government, because it would pay a higher rate of interest with equal 
security, and would attract the great body of the population to the national industries. There are excellent precedents for such a governmental guaranty. The United States Government lent its credit to the first railroads to the Pacific, and thus enabled them to be built, and the Government was repaid practically the entire amount. New York City, in building its present subways, lent its credit to the enterprise, and obtained the necessary capital on the lowest terms.

(3) The Government would take all profits after the guaranteed dividend was paid. The financial workings may be shown by a concrete example: Take the Illinois Central Railroad Company. Its capital stock $(\$ 109,296,000)$ has now a market value of $\$ \mathrm{II} 2,862,000$. It pays $5 \%$ dividends, namely, $\$ 5,464,800$ annually. Suppose its capital stock were absorbed by the "Western Regional Railroad Company" by exchange of the stock of the former for the $3 \%$ guaranteed stock of the latter or by issuing the stock of the latter to the public at par and using the money to purchase or condemn the Illinois Central stock. The financial result of the transaction would be that the "Western Regional Railroad Company" would pay out $3 \%$ dividends annually on its $\$ I I 2,862,000$ outstanding stock, in other words, pay out $\$ 3,385,860$ annually, and would receive in dividends $\$ 5,464,800$ from its Illinois Central stock. That would leave a profit to the "Regional Railroad Company" of $\$ 2,078,940$, which could be kept as a profit or used for improvements or for reduction of railroad rates. The Government would not be called on to respond to its guaranty or to pay a dollar, and yet the "Regional Railroad Company" would have control of the Illinois Central Railroad Company. Furthermore, the waste from competition pointed out by President Ripley would cease, and would be turned into an additional profit going to the Government. A railroad map of the United States will show that there are ten great main railroads which practically control the railroad transportation of this country. The outstanding capital stock of these railroads is now a little more than two and half billion dollars. That certainly is not a prohibitive sum with a government guaranty and an exchange of securities on a fair basis.

(4) Money for railroad extensions and improvements would be raised by issuing additional "Regional Railroad" guaranteed stock to the public for cash. In the first place, such a guaranteed stock would certainly be salable to investors. It would be issued from time to time, in large or small amounts; as suited the 
occasion. The rate of dividend on different issues might vary, sometimes three per cent., sometimes two and a half or three and a half or even four (the rate, of course, on each issue, when once fixed, not to be varied thereafter on that particular issue), just as issues of railroad bonds vary in rates of interest and amounts issued, according to the needs of the times. Whatever the rate, it certainly would be much less than the railroad corporations now pay, because the Government guaranty would be back of it. The present three per cent. bonds of the Government now sell at IOI $\mathrm{I} / 2$, notwithstanding the present phenomenally low price of all securities.

(5) If the plan herein suggested is impractical the recent Federal Reserve Bank Act must be impractical and all the evidence up to date points to a contrary conclusion. The Government has not gone into the banking business, but it has utilized the corporation to control the banking business. Why not consolidate the railroads in the same way? The control of American railroads is still in Wall Street, notwithstanding the crusade against the "Money Trust." And the control will continue in Wall Street unless something practical is done to prevent it. The railroads must have money, more now than ever, and yet it is becoming harder and harder to get. To obtain it they have to go to Wall Street. Nowhere else can it be obtained. The railroads are not owned by Wall Street; they are owned by investors; but they are controlled by Wall Street, as a condition of financial assistance. The plan outlined above would take the control away from Wall Street and lodge it with the public, the railroad staff, and investors.

(6) Such a plan would end wasteful competition; give to the public the profit from such saving and also the future increase of profit and increment in value of the railroads of the whole country; raise fresh money cheaply; stop the wasteful expense of Commissions; stay the flood of litigation; unite the railroads and the public, and last but not by any means least it would avoid government ownership by preserving all the advantages of that system and eliminating its dangers. It would, for instance, remove the menace of a vast national debt and a railroad deficit to be made up by taxation; it would preserve the private ownership of railroad property; and not allow it to become the hunting ground of politicians and ignorant voters, thus insuring a more efficient management of railroads than any government ownership ever did or ever could provide. It embodies the 
utilization of the corporate idea which has proved such an Aladdin's lamp for modern industries. It is not socialism, nor government ownership, nor even direct governmental control; and it is absolutely practical. It would nationalize railroads without political agitation and without costing the Federal Government a dollar.

New YoRk City.

William W. Cook. 